\title{
Ellipses Of World Literature
}

\section{Citation}

Hamilton, John T. 2014. Ellipses of World Literature. Poetica 46 (1-2): 1-16.

\section{Permanent link}

http://nrs.harvard.edu/urn-3:HUL.InstRepos:23936194

\section{Terms of Use}

This article was downloaded from Harvard University's DASH repository, and is made available under the terms and conditions applicable to Open Access Policy Articles, as set forth at http:// nrs.harvard.edu/urn-3:HUL.InstRepos:dash.current.terms-of-use\#OAP

\section{Share Your Story}

The Harvard community has made this article openly available.

Please share how this access benefits you. Submit a story.

Accessibility 


\section{ELLIPSES OF WORLD LITERATURE}

John T. Hamilton (Cambridge, MA)

In his recent essay, "Incomparable: The Destiny of Comparative Literature, Globalization or Not" (2007), Jan Ziolkowski has occasion to reflect on the field's perpetually troubling designation. He cites the case of Lane Cooper, professor at Cornell University, who, in the 1920s, as Comparative Literature departments spawned across North America, outright refused to surrender to fashion and insisted on giving his department what he believed was a far more accurate label: "The Comparative Study of Literature." As Ziolkowski concedes, the name "Comparative Literature" indeed would appear to be intelligible only when the two components are construed as shorthand, with the term comparative "denoting 'based on or involving comparison' and literature as an ellipsis for 'literary studies."'1 According to Ziolkowski, a formidable Latinist, Cooper's all-too-literal mind neglected to appreciate the elliptical force of the discipline's appellation. In Cooper's own words, "comparative literature" is a "bogus term" that "makes neither sense nor syntax"- "You might as well permit yourself to say 'comparative potatoes' or 'comparative husks."'2 If an ellipsis involves a stipulation, whereby the addressee agrees to supply what has been omitted, then Cooper irritably is in breach of contract, declining to provide mentally the parentheses that would fill out the verbal construction: "(The) Comparative (Study of) Literature."

\footnotetext{
${ }^{1}$ Jan Ziolkowski, "Incomparable: The Destiny of Comparative Literature, Globalization or Not," The Global South 1 (2007), 16-44: 21.

${ }^{2}$ Lane Cooper, Experiments in Education (Ithaca: Cornell University Press, 1942), 75; cited in Ziolkowski, "Incomparable," 21.
} 
Ellipses of all kinds have long hounded Comparative Literature, beginning with this issue of the name's descriptive inadequacies. Although it now firmly holds its place as an institution, with most major universities across the globe boasting vibrant graduate programs and with a host of professional organizations contributing to the discipline's legitimacy and autonomy, the familiar moniker has always been a matter of contention. Roughly contemporaneous with Cooper, in 1931, now referring to the standard French designation, la Littérature comparée, Paul van Tieghem also admitted that "this term is not an accurate indication of the subject and there are other healthier and clearer terms than this one."3 To be sure, despite the name's shortcomings, there was ample justification to retain Littérature comparée: first, on the basis of sheer prevalence, having been in circulation since 1830, when Abel-François Villemain used it to title his Sorbonne lectures; and second, because it aligned the study of literature with the other "comparative" disciplines that emerged throughout the nineteenth century, including Comparative Zoology, Anthropology, Anatomy, and Linguistics. Still, van Tieghem regrets that the term is wanting, omitting important aspects of his academic field. A more discriminating name would be more substantial ("healthier, clearer"). Like Cooper, he proposes "The Comparative Study of Literature" or perhaps "Comparative Literary History." Thus, van Tieghem's gesture toward correction again implies that comparative literature is an ellipsis, eliding a word or words necessary for a fully "accurate" construction.

The Greek noun leipsis (an "omission," a "minus"), derived from the verb leipein ("to leave, forsake, be wanting"), is used to form both elleipsis (a "falling short," a "defect") and ekleipsis (an "abandonment," a "failing to appear," an "eclipse"). Modern rhetoricians, from the sixteenth century on, frequently conflated ellipsis and eclipsis, interpreting both as a "leaving out," even though ellipsis is clearly formed with the prefix en-, thus denoting "an omission in (the discourse, text, or construction)." At any rate, in its syntactic sense, the term comes to signify any abbreviation, lacuna, or omission of words made consciously or not. Although Quintilian preferred to treat ellipsis as an artful figure, modeled on synecdoche, by

\footnotetext{
3 Paul van Tieghem, "La littérature comparée” (Paris, 1931)
} 
which "we understand something that is not said" (quod tacetur accipimus), he granted that many verbal omissions are little more than vicious barbarisms produced by thoughtless speech or grammatical idleness. ${ }^{4}$ For Cooper and van Tieghem, "comparative literature" and "littérature comparée" are ellipses in this latter sense: unfortunate accidents of language that are now deeply entrenched in popular usage, compelling scholars to broadcast their work deficiently for lack of "healthier and clearer terms." Sadly, the current names put the discipline itself at risk, leaving it scantily clad out in the cold, letting it shiver while the sun of sufficient reason rests in total eclipse.

Benedetto Croce had already sounded a similar alarm back in 1903, when he disparaged Letteratura comparata as an utterly incomprehensible designation for what appears to be a meaningless practice. Goaded by a recent trip to New York, where he fell upon the freshly established Journal of Comparative Literature, Croce dismissed this type of scholarship as vain erudition at best. Ignorant of the essence of artistic creativity and lacking a defined field of study, Comparative Literature hardly counts as a discipline, content merely with exploring "le vicende, le alterazioni, le aggregazioni, gli svolgimenti e gli influssi reciproci" of literary themes. ${ }^{5}$ However, Croce was heartened by the editorial work of Max Koch who, having founded the Zeitschrift für vergleichende Literatur in 1887, eventually supplemented it with a second journal, Studien zur vergleichenden Literaturgeschichte, established in 1901. Croce surmised that Koch came to realize that the concept of "comparative [compared or comparing] literature" obfuscated by omission the true character of the scholarship and therefore ultimately demanded a more fitting designation. 6 To illustrate, Croce translates Koch's own description of what "comparative literary history" should entail:

[It must pay special attention] "all'intimo legame tra storia politica e storia letteraria, il quale, forse, di solito, non è messo in rilievo in tutta la sua importanza; e

\footnotetext{
4 "Quidam synecdochen vocant et cum id in contextu sermonis quod tacetur acipimus: verbum enim ex verbis intellegi, quod inter vitia ellipsis vocatur [...]. Mihi hanc figuram esse magis placet." Quintilian, Inst. orat. 8.6.21.

5 Benedetto Croce, "La 'Letteratura comparata'" [1903], in Manuale storico di letteratura comparata, Armando Gnisci and Franca Sinopoli, ed. (Rome: Meltemi, 1997), 73-78: 74.

${ }^{6}$ Croce, "La 'Letteratura comparata", 77. On this point, see Susan Bassnett, Comparative Literature: A Critical Introduction (Oxford: Blackwell, 1993), 2-3.
} 
al legame tra storia della letteratura e storia dell'arte, svolgimento letterario e svolgimento filosofico, u.s.w."7

For Croce, it is especially Koch's und so weiter that deserves comment, for this comparative historical approach moves tirelessly beyond the superficial collection of themes, recognizing that it must penetrate more deeply and consider "everything" - “'tutti' gli antecedenti dell'opera letteraria, vicini e lontani, pratici e ideali, filosofici e letterari, legati in parola o legati in forme plastiche e figurative: und so weiter." Koch's standard, casual clausula-u.s.w.—may appear semantically empty, funneling the paragraph out into silence, but it in fact betokens an infinite fullness, economically interrupting an accumulative list that thereby never ends. Whereas the name "comparative literature" camouflages the nature of Koch's real work-"comparative literary history" - the latter term itself harbors an elliptical nature by necessarily referring to the plenum of transcultural and transhistorical material, all the antecedents, links, and forms that can only be expressed by the exhaustive and exhausted legerdemain of and so forth. By omitting further reference to finite fields, the ellipsis marked by und so weiter opens onto an infinite task. It is worth recalling that the abbreviating formula that Latin renders as et cetera is rendered in ancient Greek as kai ta loipa ("and the rest"), which tellingly employs the adjectival substantive of our elliptical verb leipein...

This marked ellipsis, which poses as a minus but indicates a plus, is different from the "deficiency" discerned in the name comparative literature, which is disparaged for confusing a body of work ("literature") and the interpretation of that work ("literary studies"). Certainly, however, the conventions of English warrant using "literature" as an ellipsis for "literary studies." As the Oxford English Dictionary attests, the primary meaning of "literature," dating back at least to the fifteenth century, is "familiarity with letters or books; knowledge acquired from reading or studying books"; the narrower sense of "printed matter" being but a later

\footnotetext{
${ }^{7}$ Croce, “La 'Letteratura comparata'”, 77.
} 
development of the nineteenth century. ${ }^{8}$ All the same, Lane Cooper et alii did raise an important point, which becomes ever more crucial when we turn to Comparative Literature's longtime running mate, "World Literature." Boasting an honored provenance from Goethe, who famously predicted the obsolescence of national literatures in favor of a grander, humanist Weltliteratur, and later receiving ratification in Marx and Engels' Communist Manifesto, World Literature has of late come to the fore as a redeeming, cosmopolitan conception for a discipline perceived as fatally Eurocentric. In contrast to the institutional history of Comparative Literature, which was purportedly concerned with tracing and thus essentializing the cultural roots of national identities, World Literature would be emphatically transnational, introducing an expansion that would allow comparatists to realize their utopian dream of attaining encyclopedic breadth by means of ethically equitable, ecumenical scholarship. Yet, given the massive efforts to incorporate curricular changes and publish representative anthologies of primary sources, the meaning of World Literature tends to oscillate uncomfortably between material and mode of analysis, between a vast collection of work and a proposed methodology. What, indeed, is World Literature? Are we dealing with noeses (processes of thought) or with noemata (objects of thought)? Does the term refer to a delimited set of texts? Or does it imply rather a particular approach for studying these texts, an approach that entails a specific series of questions? ${ }^{9}$ Faced with the indistinctness of the explanandum and the explanans, one is tempted to rehearse the old frustration: Should "World Literature" be read literally or elliptically?

It bears noting that, beyond the issue of nomenclature, both Comparative and World Literature frequently inspire elliptical formulations from their practitioners, signaling a fundamental uncertainty in those who are pressed to provide a clear definition of what in fact they do. In his official report for the American Comparative Literature Association (ACLA), composed in the early 1990s, when the field was

\footnotetext{
8 Oxford English Dictionary, s.v. "literature."

${ }^{9} \mathrm{Cf}$. Xavier Landrin, "La sémantique historique de la Weltliteratur: genèse conceptuelle et usages savants," in A. Boschetti, ed., L'espace culturel transnational (Paris: Nouveau Monde Editions, 2010), 73-134: 74.
} 
beset by the growing demands of "multiculturalism," Charles Bernheimer eloquently stammered forth a response:

Comparison is indeed the...what is it?-activity, function, practice? all of these?that assumes that our field will always be unstable, shifting, insecure, and selfcritical. $^{10}$

Possessing neither a specific object of study nor a distinguishing methodology, never occupying a single field, belonging everywhere and hence nowhere, comparatists have long been accustomed to the harried nature of being in permanent crisis. In Bernheimer's language, the ellipsis-graphically marked by the conventional three points de suspension and reinforced by the intervening questions, the asyndeta, and the long dashes-vividly conjures the feelings of haste, urgency, and anxiety that the literary scholar is wont to convey. That is to say, here the ellipsis is clearly being employed as a trope. Expressing a failure to express, it is a gesture of disruption or reticence, a nearly pious Abbruchsformel, akin to classical aposiopesis and its relation to conflicting emotions.

In a positive light, Bernheimer's elided statement, coupled with groping queries, displays an open-endedness, albeit in a way that differs from the und so weiter singled out by Croce, for Bernheimer alludes to a radical indeterminacy, which is nothing other than the fundamentum concussum of comparative work. That said, he also appears to rely on the ellipsis-contract, whereby his immediate addressees-the members of the ACLA-implicitly agree to supply the sense of the lacunae, each according to his or her inclination. For, as rhetoricians have always known, the omission of a word or words invites the participation of the listener or reader, who is driven to fill in what is missing. The imposed lack leaves room for full, non-prescriptive potential. Bernheimer's stuttering description thereby becomes a call to action: Comparative Literature must uphold its definition as something indefinable; and comparatists must cultivate an ear for the deficiencies that other scholars might ignore. If, as Croce feared, Comparative Literature is ellipticalfalling short of a definite methodology, field, or stable perspective-it is precisely

\footnotetext{
${ }^{10}$ Charles Bernheimer, "The Anxieties of Comparison," in Comparative Literature in the Age of Multiculturalism (Baltimore: Johns Hopkins University Press, 1994), 2 (ellipsis in text).
} 
these disciplinary shortcomings that enable it to uncover how well-defined approaches prove to be insufficient.

Especially for today's comparatists who have adopted a World Literature outlook, omissions are readily discernible in earlier studies, which were so informed by a nationalist paradigm that their authors failed to acknowledge any deficit whatsoever. In his essay "Toward a History of World Literature" (2008), David Damrosch indicates how the title of Ian Watt's overview, The Rise of the Novel (1957), is an adequate representation of the book only when the reader takes "the Novel" as an ellipsis for "the British Novel"; for indeed, Watt restricts his analyses to Defoe, Richardson, and Fielding, without any regard for the development of the genre in Cervantes or Madame de Lafayette, not to mention novelistic precedents in Heliodorus or Apuleius, in Norse saga or in The Tale of Genji. For Damrosch, the idea and ideal of "Comparative Literature" has always been poised to supply what is excluded in other troublingly elliptical projects. With the global scope named by the rubric of World Literature, it is more than ever prepared to take into account "the varied processes and strategies through which writers have individually and collectively furthered the long negotiation between local cultures and the world beyond them."11

Damrosch consistently champions some idea of "negotiation" whenever he attempts to elucidate the salutary effects and benefits of World Literature for the study of literature in general. To be sure, he is very much aware of how, in the past, what presented itself as World Literature was damningly narrow. Originally limited to a closed set of ancient yet timeless classics, which were said to transcend particular cultural and historical contexts, it subsequently came to denote a valued collection of masterpieces, a gallery of major achievements of art, ancient and modern alike, which were deemed capable of inspiring engagement in great ideas shared by all mankind. Only recently has it designated a vast repertoire of diverse, potentially alienating works, which stand available for the reader eager to

\footnotetext{
11 David Damrosch, "Toward a History of World Literature," New Literary History 39 (2008), 481-95; 485.
} 
encounter difference. ${ }^{12}$ According to Damrosch, every one of these versions-the "classic," the "masterpiece," and the "window onto otherness"- bears the risk of attracting serious critiques, namely "that the study of world literature can very readily become culturally deracinated, philologically bankrupt, and ideologically complicit with the worst tendencies of global capitalism."13 Settling the ontological problem of the content of World Literature would hardly resolve the epistemological problem of how this content should be critically examined. Both issues are further exacerbated by the expansion of the globalized, electronic environment in which we now live, where the accessibility of materials has reached unprecedented proportions. How would anyone ever be capable of taking such an inordinate wealth of texts into consideration? What is to become of the hallowed trade of close reading? How many languages can be truly mastered? What role should translation play and would it not severely curtail the kind of philological work that has been the proud distinction of literary studies?

Given these questions and many others, it is no surprise that proponents of World Literature tend to spend a good deal of time defining and defending their métier, and not simply out of paranoia. Detractors are legion. In the early 1990s, while the journal World Literature Today flourished under the directorship of Djelal Kadir as the primary organ of postcolonial studies, Claudio Guillén rightfully balked at the very notion of "World Literature":

What can one make of such an idea? The sum total of all national literatures? A wild idea, unattainable in practice, worthy not of an actual reader but of a deluded keeper of archives who is also a multimillionaire. The most harebrained editor has never aspired to such a thing. ${ }^{14}$

Guillén's exasperated tone, variously modulated, continues to resonate to this day, from Gayatri Chakravorty Spivak's obituary, Death of a Discipline (2003) ${ }^{15}$ to Emily

\footnotetext{
${ }^{12}$ Cf. David Damrosch, What is World Literature? (Princeton: Princeton University Press, 2003), 15.

13 "Comparative Literature/World Literature: A Discussion with Gayatri Chakravorty Spivak and David Damrosch," Comparative Literary Studies 48 (2011), 455-85: 456.

${ }^{14}$ Claudio Guillén, The Challenge of Comparative Literature (Cambridge: Harvard University Press, 1993), 38. Damrosch cites and discusses this remark in What is World Literature?, 4.

${ }^{15}$ Gayatri Chakravorty Spivak, Death of a Discipline (New York: Columbia University Press, 2003), see especially pp. 10, 21-22, and 44.
} 
Apter's most recent polemic, Against World Literature (2013). ${ }^{16}$ Striving to navigate between the Scylla of European exceptionalism and the Charybdis of vapid literary tourism, Damrosch focuses his attention on the movement of texts and their particular trajectories, taking World Literature to refer to "all literary works that circulate beyond their culture of origin, either in translation or in their original language." 17

Strikingly, Damrosch calls for "an elliptical approach," not in reference to the grammatical phenomenon, but rather to "the image of the geometric figure that is generated from two foci at once":

Contemporary America will logically be one focus of the ellipse for the contemporary American reader, but the literature of other times and eras always presents us with another focus as well, and we read in the field of force generated between these two foci. [...] If we can plot a series of partially overlapping ellipses on our literary globe, we can create a new and dynamic understanding of the world's multiform literatures, and our own multivalent place among them. ${ }^{18}$

Here, the ellipses of World Literature are entirely recalibrated. Whereas earlier work in World Literature could be reprimanded for its elliptical deficiencies, Damrosch envisions a method that is ellipsoid, decentering a predominant Euro- or even Anglocentrism by including a second center from afar. Like Johannes Kepler, who revolutionized the Copernican revolution by positing the Sun's "fireplace" (focus) as one of two points determining planetary orbits, Damrosch wants to emphasize World Literature's eccentricity, allowing for a hermeneutic push and pull, between identity and difference, ipseity and alterity. Nevertheless, the question remains whether the oversized hearth of American influence will not ultimately outshine the gravity of otherness, imposing anew the heliocentric monolingualism that well-intentioned comparatists fear. How can anyone insure that processes of homogenization will not cast difference into the shadows? How can anyone prevent this eclipse of the foreign? In brief, how might Damrosch's ellipsoid ideal possibly escape the condemnation of being elliptical? After all, although English, unlike

\footnotetext{
16 Emily Apter, Against World Literature: On the Politics of Untranslatability (London: Verso, 2013), see especially p. 2.

17 Damrosch, What is World Literature?, 4.

18 Damrosch, "World Literature Today," Symploke 8 (2000), 7-19: 18-19.
} 
German and French, distinguishes between the rhetorical ellipsis and the geometrical ellipse, it is at least possible to think the two forms together. To borrow Gertrude Stein's syntax, an ellipsis is an ellipsis is an ellipsis...

It would be worthwhile to review briefly how we arrived at the opposing meanings between a rhetorical ellipsis, which expresses a subtraction of words, and a geometric ellipse, which denotes an addition of centers. According to Plutarch, it was Plato who assigned Menaechmus the mathematician with the task of solving the socalled "Delian Problem" of doubling the cube. ${ }^{19}$ Upon consulting the Delphic oracle, the citizens of Delos learned that they must double the cuboid altar to Apollo in order to rid themselves of a horrific plague. Plato interpreted this message as the god's command to cultivate the science of geometry. ${ }^{20}$ However, the philosopher was displeased when Menaechmus abandoned number theory and instead turned to mechanical contrivances, namely by cutting a cone to produce the "acute-angled section" that led to the mathematical solution. ${ }^{21}$ A century later, when Apollonius of Perga prepared his Treatise on the Conic Sections, he named this closed, oblong curve an elleipsis, a "falling short," because the figure's "eccentricity" (the ratio of distance between the focus and the directrix) is less than 1. Apollonius designated each of the conic sections with concrete precision: the parabole (an "even comparison or juxtaposition") with an eccentricity equal to 1; the hyperbole (an "overshooting") with an eccentricity greater than 1 ; and the circle, which is perfectly centered, that is, without any eccentricity. ${ }^{22}$

Independent of geometric analysis, ancient grammarians would come to apply the same terms to denote figurative devices and narrative forms: hyperbole ("overstatement"); the parable (an equally corresponding "comparison"-in

\footnotetext{
${ }^{19}$ Plutarch, Quaest. conviv. 8, Q. 2.1.

20 Plutarch, De E, 6.

${ }^{21}$ See Proclus's account in Proclii Diadochi in primum Euclidis elementorum librum, G. Friedlein, ed. (Leipzig: Teubner, 1873), 111-12; also, Plutarch, Vita Marcelli, 14.5. For a comprehensive discussion of the extant sources, with ample bibliography, see George J. Allman, Greek Geometry from Thales to Euclid (Dublin: Hodges, Figgis, \& Co., 1889), 155 - 179.

${ }^{22}$ Apollonius of Perga, Treatise on the Conic Sections, Prop. 1.13. For a complete account, see Thomas Little Heath's introduction to Apollonius of Perga: Treatise on the Conic Sections (Cambridge: Cambridge University Press, 1896), xvii-xxx.
} 
German, Gleichnis); and, of course, the ellipsis, which designated any verbal "falling short," whether it occurred by contingency or by rhetorical design. Following Quintilian's suggestion to consider the ellipsis as a trope, modern rhetoricians pored over classical texts to locate examples of what George Puttenham characterized as "the Figure of default." 23 Together with other terms derived from leipein-primarily syllepsis and prolepsis-ellipsis (or eclipsis) was regarded as a highly effective device, entirely in accordance with "nature." As John Duncan Quackenbos explained in his Practical Rhetoric (1896), it could be understood as he very hallmark of genius:

Art everywhere deals in Ellipsis, the unseen is imagined from the visible. And so it is in nature. Many things in the universe we know only by inference from what is seen - notably nearly one-half of the nearest heavenly body, our moon. "The artist," said Schiller, "is known by what he omits." Likewise in literature, the true artist is revealed by his tact of ellipsis. ${ }^{24}$

Still, an ellipsis in scholarship may not be as valued as one in art. While Franco Moretti, with his trumpeted call for "distant reading," 25 may be criticized for dispatching philology to the dark side of the moon, David Damrosch could never be accused of any such lunacy. Damrosch is acquitted of this charge, because he consistently engages the geometric ellipse of bifocality and not the syntactic one of deficiency. In the conclusion to What is World Literature? he makes good on his title's Sartrean promise by offering a list of bullet points, beginning with the key figure:

1. World Literature is an elliptical refraction of national literatures.

2. World Literature is writing that gains in translation.

3. World Literature is not a set canon of texts but a mode of reading: a form of detached engagement with worlds beyond our own place and time. ${ }^{26}$

As Damrosch is quick to admit, among these three foci, which represent the context, the object, and the reception of literature, the first is the least self-evident, insofar as

\footnotetext{
${ }^{23}$ George Puttenham, The Arte of English Poesie (London: Richard Field, 1589), 136. See also Johannes Susenbrotus, Epitome troporum ac schematum et grammaticorum \& rhetorum (Zürich: C. Froschouer, 1540), 25; and Henry Peacham, The Garden of Eloquence (London: 1577), sect. 1.2.2.

${ }^{24}$ John Duncan Quackenbos, Practical Rhetoric (New York: American Book Co., 1896), 268.

${ }^{25}$ Moretti first broaches the concept of "distant reading" in "Conjuecture on World Literature," New Left Review 1 (2000), 54-68. His argument, which in fact aims to rectify the ellipses that threaten any attempt to deal with literature on a planetary scale, is elaborated in his latest book, Distant Reading (London: Verso, 2013).

26 Damrosch, What is World Literature?, 282.
} 
it employs a provocative description - "elliptical refraction" — which itself demands explication. Building on the definition's distinction between "world literature" and "national literatures," the subsequent explanation alights on the metaphor of travel, specifying the idea of "national" as relating to a work's original cultural neighborhood before it goes on to circulate in the world at large. To be sure, the travel metaphor is only partially operative, given the fact that there is no suggestion, at least initially, of any return. The centrifugal is emphasized at the expense of the centripetal. Accordingly, the discussion presses on with accounts of growing divergence and diffusion. We are reminded that literary productions bear constitutive birthmarks that accompany the text's journey abroad, "yet these traces are increasingly diffused and become ever more sharply refracted as a work travels farther from home" (283). By cancelling the return flight, Damrosch allows the metaphor of travel to blend with an image from physics or even astronomy-a rhetorically sound move, to the extent that both voyage and refraction denote a change in direction. The shift from one location to another corresponds to the shift in a line's angle when it passes from one medium to the next. Already with this image of refraction, it becomes clear how the initial definition's three foci may relate to each other. The implied movement accounts for how the text "gains in translation" as well as for how the reader finds the opportunity for "detached engagement" with other worlds. With this last point, in addition to the obvious ethical ramifications, a faint hint of vicarious nostalgia creeps in, a longing to send the foreign text back home, to compensate for the work's protracted stay away from its origin. From the reader's perspective, world literature's value depends on the round trip.

Hence, the "refraction" must be further qualified as "double":

Even a single work of world literature is the locus of a negotiation between two different cultures. [...] World literature is thus always as much about the host culture's values and needs as it is about a work's source culture; hence it is a double refraction, one that can be described through the figure of the ellipse, with the source and host cultures providing the two foci that generate the elliptical space within which a work lives as world literature, connected to both cultures, circumscribed by neither alone. (283) 
The figure of the ellipse expands or elongates the circle, which is put out of play ("circumscribed by neither"), and thus modifies the notion of refraction by allowing two shifts in direction, two bends-"two foci." Disregarding for now the curious slippage from the three foci of the initial definition to the two that round it out (albeit ovally), it would be worthwhile to analyze this final metaphorical shift. Having begun with a metaphor of travel, we wander into the field of optics, only to end up in the realm of geometry. Calling attention to these shifts should not suggest that the figures employed are not justified, both individually and collectively. Their descriptive power is undeniable, offering rich insight into what the concept of World Literature entails and how it functions in practical terms. Yet, metaphors are rarely as controllable as constructed concepts. Employing bold figures brings with it the risk of unintended meanings and connotations. For this reason, the rapid alteration of images that drives Damrosch's account may be ascribed, consciously or not, to a need for constant recalibration, so as to secure the discourse before it escapes critical management. By means of frequent scene changes, the author restricts the chance of any one metaphor drifting too far afield.

Perhaps the most famous usage of the figure of the ellipse to describe literature is found in Walter Benjamin's description of Franz Kafka's stories. In a letter to Gershom Scholem, Benjamin writes:

Kafkas Werk ist eine Ellipse, deren weit auseinander liegende Brennpunkte von der mystischen Erfahrung (die vor allem die Erfahrung von der Tradition ist) einerseits, von der Erfahrung des modernen Großstadtmenschen andererseits, bestimmt sind. ${ }^{27}$

In somewhat fanciful fashion, Benjamin responds to Scholem's elliptical understanding of Kafka's mysticism by reconfiguring the writer's work as an ellipse. There is not one central determinant in Kafka's work, but two. The implicit question, then, is whether, at least according to Benjamin, the two foci that determine Kafka's work as an ellipse also cause it to be elliptical in some other sense. Benjamin appears to answer precisely this question further on in the letter:

\footnotetext{
27 Benjamin to Scholem, (Paris, June 12, 1938), in Briefe, 2 vols., G. Scholem and T.W. Adorno, ed. (Frankfurt am Main: Suhrkamp, 1978), 2: 760.
} 
Kafkas Dichtungen sind von Hause aus Gleichnisse. Aber das ist ihr Elend und ihre Schönheit, daß sie mehr als Gleichnisse werden mußten. Sie legen sich der Lehre nicht schlicht zu Füßen wie sich die Hagada der Halacha zu Füßen legt. Wenn sie sich gekuscht haben, heben sie unversehens eine gewichtige Pranke gegen sie. (2: 763)

To say that Kafka's work is an ellipse is to suggest that it does not consist straightforwardly in parables. Although here Benjamin uses the German term Gleichnis for "parable," elsewhere he refers to Parabel-the name for yet another conic section, the parabola. As already remarked, the parabole denotes "juxtaposition" or a "comparison by moving from one side to the other," where both sides are equal, where both sides perfectly correspond, where the eccentricity is equal to one. Kafka's parables are excessive-"more than parables"-miserably unable to give any adequate version of divine truth or law. ${ }^{28}$ The Kafkan parable gives only itself, excessively and beautifully, falling short of veridical correspondence by falling before it. Kafka's work is an ellipse.

In his chapter devoted to Kafka's literary afterlife, "Kafka Comes Home," Damrosch adduces the ellipse, not as a figure internal to Kafka's work but rather as one that dynamically shapes its reception. To this end, Damrosch assesses the work of recent editors, translators, and critics, who respect today's emphasis on cultural context and therefore aim to reconnect Kafka's writing to its original Czech and Jewish conditions. Efforts are thereby made to eradicate the universalizing tendencies of an earlier Rezeptionsgeschichte, which, immediately after the Second World War, endeavored to turn Kafka into a lonely, existentially overwrought, nonlocalizable Everyman. Subsequently, Gilles Deleuze and Félix Guattari's seminal study, Kafka: Pour une littérature mineure (1975), set the stage for appreciating Kafka as "minor" figure, presented to an audience now ready to engage with cultural difference, to grapple with a body of work without cosmeticizing over its distracting birthmarks, and thus to experience regional specificity on its own terms. In literary scholarship, this interest corresponds to a shift in concern from textual hermeneutics to contextual encounter. Damrosch cites Mark Anderson's diagnosis:

\footnotetext{
${ }^{28}$ For further analysis on the implications of Kafka's "inadequacy" or "failure," see Werner Hamacher, "The Gesture in the Name: On Benjamin and Kafka," in Premises: Essays on Philosophy and Literature from Kant to Celan, P. Fenves, trans. (Cambridge: Harvard University Press, 1996), 294-336.
} 
Whether Freudian, existentialist, New Critical, structuralist, or poststructuralist, these interpretations have offered readings of individual texts in terms of a critical methodology that tended to eclipse the historical dimensions of Kafka's texts. Rooted in no particular culture or period, so ran the implicit assumption, his writings seemed to be meant for all cultures, thus providing an example of the hermetic, anonymous, sui generis modern artwork that apparently validated these very formalist, ahistorical methodologies. ${ }^{29}$

In other words, the readings that "tended to eclipse the historical dimensions" are shown to be elliptical, eliding the radical foreignness that would break the vicious circle of formalism. Damrosch picks up on Anderson's trope, when he suggests that the new Kafka translations, which renounce earlier, domesticating criteria, is responsible for the fact that Kafka "now seems to be eclipsing Thomas Mann" in the field of literary studies (188), with "historicist models now often eclipsing formalist models" (190).

One eclipse or ellipsis deserves another. By revealing how Kafka falls short of assimilation, Damrosch demonstrates to what extent the writer's work can influence the ellipsoid orbit that is World Literature-until, of course, the eccentricity of the text is reduced to zero, falling short of falling short. A circle, including both hermeneutic and vicious ones, is not qualitatively different from an ellipse: the circle's foci simply coincide. As the ancient mathematicians have shown, a continuum obtains from one conic section to the next. Given that rhetoric has shared its terminology with geometry, it might be enlightening to apply the figures to the ongoing development of Comparative Literature's relation to the literatures it compares. We could begin with the circle at the cone's tip and decline through the ellipse, the parabola, the hyperbole, and then back again; that is, we could begin with the perfect coincidence between object and method and then move through elliptical deficiency, parabolic equality, and hyperbolic excess, before progressing or regressing through the process again, and so on, und so weiter... Alternatively, we

\footnotetext{
${ }^{29}$ Mark Anderson, Kafka's Clothes: Ornament and Aestheticism in the Habsburg Fin de Siècle (Oxford: Clarendon, 1992), 9-10; cited in Damrosch, What is World Literature?, 189-90.
} 
could turn the cone on its head and give a poet the last word, soliciting Christian Morgenstern's incomparable funnel ${ }^{30}$ :

Zwei Trichter wandeln durch die Nacht. Durch ihres Rumpfs verengten Schacht

fliesst weisses Mondlicht

still und heiter

auf ihren

Waldweg

u. s.

W.

30 Christian Morgenstern, "Zwei Trichter" (1905), in: Das Wasserzeichen der Poesie oder die Kunst und das Vergnügen Gedichte zu lesen: In hundertvierundsechzig Spielarten vorgestellt von Andreas Thalmayr [= Hans Magnus Enzensberger] (Nördlingen: Greno, 1985), 313. 